\title{
The Dimensions of Place Meanings
}

\author{
Maarja Saar \\ Center for Landscape and Culture \\ Estonian Institute of Humanities \\ Tallinn University \\ Uus-Sadama 5, 10120 Tallinn \\ email: maarjasaar@gmail.com \\ http://www.tlu.ee/ \\ Hannes Palang \\ Center for Landscape and Culture \\ Estonian Institute of Humanities \\ Tallinn University \\ Uus-Sadama 5, 10120 Tallinn \\ email: palang@tlu.ee \\ http://www.tlu.ee/
}

Accepted on 29 June 2009

Published on 29 July 2009

\begin{abstract}
This article aims to give an overview of how place meanings are created and how they influence people's sense of belonging. It should be noted that the current literature has various shortcomings which mostly result from the lack of interdisciplinary research. The studies in place attachment usually focus on personal sense of belonging leaving aside those extending over various scales - such as, for instance, national identity. Also, place meanings and identity are primarily discussed as the very personal phenomena. On the contrary, place making and shaping is usually seen through more structural viewpoint by claiming that places mainly change in result of political or economic processes. Nowadays, there are even claims that due to the influx of globalization place no more matters and similar processes will happen everywhere. This notion does not take into account the special character of every place and the fact that outside forces come together in different ways in every place. Authors suggest that these different perspectives need to be united in order to fully grasp the character of place making and place meanings. In current articles, authors have adopted the multi-disciplinary approach and understood the place as uniting different processes starting from deeply personal meaning creation and ending with changes happening in global scale.
\end{abstract}

Keywords: place meanings, place attachment, meaning creation

This review is licensed under a Creative Commons Attribution-Non-Commercial-NoDerivs 3.0 Germany License. http://creativecommons .org/licenses/by-nc-nd/3.0/de/ 


\section{Imprint / Terms of Use}

Living Reviews in Landscape Research is a peer reviewed open access journal published by the Leibniz Centre for Agricultural Landscape Research (ZALF), Eberswalder Straße 84, 15374 Müncheberg, Germany. ISSN 1863-7329.

This review is licensed under a Creative Commons Attribution-Non-Commercial-NoDerivs 3.0 Germany License: http://creativecommons.org/licenses/by-nc-nd/3.0/de/

Because a Living Reviews article can evolve over time, we recommend to cite the article as follows:

Maarja Saar and Hannes Palang,

"The Dimensions of Place Meanings",

Living Rev. Landscape Res., 3, (2009), 3. [Online Article]: cited [<date $>$ ], http://www.livingreviews.org/lrlr-2009-3

The date given as $<$ date $>$ then uniquely identifies the version of the article you are referring to.

\section{Article Revisions}

Living Reviews supports two different ways to keep its articles up-to-date:

Fast-track revision A fast-track revision provides the author with the opportunity to add short notices of current research results, trends and developments, or important publications to the article. A fast-track revision is refereed by the responsible subject editor. If an article has undergone a fast-track revision, a summary of changes will be listed here.

Major update A major update will include substantial changes and additions and is subject to full external refereeing. It is published with a new publication number.

For detailed documentation of an article's evolution, please refer always to the history document of the article's online version at http://www. livingreviews.org/lrlr-2009-3. 


\section{Contents}

1 Background 5

2 The concept of space and place $\quad 6$

2.1 Supranational place making, place meanings . . . . . . . . . . . . . . . . 7

2.2 National place making . . . . . . . . . . . . . . . . . . . . . . . 9

2.3 Local place making . . . . . . . . . . . . . . . . . . . . . . . 9

2.4 Individual place making . . . . . . . . . . . . . . . . . . . . 11

3 Unifying the dimension $\quad 13$

4 Place attachment and exclusion $\quad 15$

5 Place-making and change $\quad 16$

$\begin{array}{lll}6 & \text { Conclusion } & 17\end{array}$

7 Acknowledgements $\quad 18$

$\begin{array}{ll}\text { References } & 19\end{array}$ 



\section{Background}

Landscape is perhaps one of the most contested and (mis)interpreted concepts in (human) geography and other disciplines. Different theoretical approaches and methodologies have been created for exploring and explaining the relationship between humans, environment and landscape (Cosgrove, 1998; Jones, 2003). Humanistic geographers have drawn on the concept of place when studying the human/environment or human/landscape relationship. Contrary to landscape, place provides a midway between an objective fact and a subjective feeling, which Entrikin (1991) calls the betweenness of places. It appears as a combination of objects and meanings that differs somehow from its surroundings, regardless of scale.

Why use places in landscape studies? And has landscape ecological research - the main focus of this journal - anything to do with places, senses of places, place making etc.? There are many reasons for dealing with places. First, there are opinions that landscape as a concept is mostly about the visual and therefore studying places gives better access to how people act in landscapes. Cresswell (1996, p 11) even announced that "we do not live in landscapes - we look at them" a statement we definitely disagree with. Still, Spirn (1998), see also Olwig (2002), argued that the term land denotes both the place and the people living in it, and scape or schaffen means "to form", and Olwig (2008) has shown the origin of the term landscape being close to the Greek word choros, and thereby landscape itself should be understood as a land or place shaped by somebody. Thereby place and landscape are interlinked.

Second, both Vorkinn and Riese (2001) and Derr (2002) have stressed the importance that place attachment plays in environmental concerns. Vorkinn and Riese (2001) state that those who are attached to an area may be more sensitive to site impacts and they may be less willing to displace a recreational area due to environmental changes and Derr (2002) notes that the sense of place is important in maintaining the quality of environment. We need to have an overview of people's landscape perceptions since, as Gobster et al. (2007) claim, places which are found to be beautiful are more likely protected.

Further, Nassauer and Opdam (2008) point that landscape ecology should also focus on design, not only patterns and processes. If this is the direction, landscape ecology cannot avoid involving people, focusing on participatory planning (see, e.g., Luz (2000), Ghose and Elwood (2003), stakeholder approach (Potschin and Haines-Young, 2006) or whatever one feels appropriate. For lay people landscape is often too large a concept and they prefer to speak about places (see Soini, 2001; Alumäe et al., 2003; Kaur et al., 2004, etc.). Hence it might be useful to look across the disciplinary boundaries and see what has been achieved in other realms in the field of place studies.

Various authors have discussed over the importance of involving place meanings and attachment to participatory planning (Selman, 2006; Manzo and Perkins, 2006, etc.). Manzo (2003) argues, that when understanding place meanings the roots of some community conflicts can be manifested. There is a body of substantiated literature (see Yuen, 2005; Cook et al., 2007; Fried, 2000; Daniel and Vining, 1983) which also stresses on the need to more closely relate place attachment studies in participatory planning by indicating various positive effects that such involvement has, for instance, the fact that place attachment increases residential satisfaction. However, one should also be aware of the calls by, e.g., Healey (1996) and (1998) to change the planning paradigm and move on to the collaborative discourse.

Place is a central word of our everyday language, although there exist differences in the ways it is used in various languages. In addition to its everyday usage, the concept has been adopted by various academic disciplines. Place, though, like landscape (Cresswell, 2003; Setten, 2004), has remained elusive and difficult to deal with in research and despite various attempts, place does not lend itself to a single definite interpretation. Its definitions and approaches vary from phenomenological ones to more or less behavioral ones. Lewis $(1979, \mathrm{p} 28)$ has stated that "It is often easier to see its results in human behavior than to define it in precise terms", which is why in the following Section 2 we will discuss the definition of place and various dimensions behind it. 
Maarja Saar and Hannes Palang

\section{The concept of space and place}

The concepts of place and space have varied throughout the recent history of geography. In the following, different explanations that are given to places are being viewed. In this section we leave aside disciplines that have concentrated only on one dimension of place such as, for instance, gender studies that mainly stress on the masculine spaces or historical materialism which sees places mainly as socially produced (Hubbard et al., 2004). However, all these approaches are present in our further analysis when we refer to the multidimensionality of place and discuss different aspects of place that various researches have tackled.

We start our discussion with phenomenology and humanistic geography. Entrikin (1991) has illustrated quite well the idea grounded in the humanistic discipline by dividing place into objective and subjective. The subjective dimension embraces individualistic meanings attached to place basically in the representational level whereas the objective denotes to the 'naturalistic qualities of place'. What Entrikin (1991) calls the betweenness of places is the meeting point for the subjective and objective space, place where meanings and objective reality encounter.

However, this approach has been criticized for various reasons. Firstly, authors following the non-representational approach have been debating the understanding of subjective character only on the mental level, leaving aside sensual and physical performances in place (Thrift, 2000). Secondly, Merrifield (1993) argued that Entrikin flaws in his basic assumption when assuming that the observer and the observed are somehow detached. The phenomenological approach, according to him, rather seeks ways to understand how the two polar opposites can be brought together rather than to comprehend that place is a unity containing within itself different aspects. However, in our opinion this binary approach in humanistic discipline is mainly used to lead attention to meanings which had been neglected prior to this approach. Still, the way meanings are brought to the analysis needs further attention.

Lefebvre (1991) challenged the binary notion by introducing the third term. Lefebvre, and later also Soja (1996), argue that space is understood as physical and social landscape which is imbued with meaning in everyday place-bound social practices and emerges through processes that operate over varying spatial and temporal scales. Three different scales are distinguished. Firstly, perceived space, which includes both the emotional and behavioral bubbles which invisibly surround people's bodies as well as complex spatial organization of practices that shape action spaces in households, buildings, neighborhoods, villages, cities, regions, nations, the world economy and global geopolitics. Secondly, conceived space refers to our knowledge of spaces which is primarily produced by discourses of power and ideology constructed by professionals such as planners, engineers, researchers etc. Eventually, thirdspace is the space where all the spaces are and where the subjectivity and objectivity, the abstract and the concrete etc. meet. This encompasses at the same time the space of users in everyday life, the mental space, the space influenced by wider social, economic and political processes etc.

However, although the division has different logic from those of humanists, in our opinion the final idea of thirdspace is somewhat similar to that of Entrikins betweenness of places - they both aim to bring together something that cannot be separated. It must, however, be acknowledged that the structuralist approach stressed on uniting space and claimed that processes happening in space are actually inseparable.

The postmodern approach has even more emphasized the inseparable character of place. For instance, Jessop et al. (2008) stressed the need for interdisciplinary research. Despite their focus being on socio-spatial relations in their TPNS (territory, place, network, scale) model, the model presents how place has also been approached in different times. Although the presence of place in the framework may be misguiding, in this context it actually denotes more the specific location. In their article, Jessop et al. claim that different approaches should be used simultaneously when investigating place - place should be viewed as specific location, as a wider territory, as consisting

Living Reviews in Landscape Research

http://www. livingreviews.org/lrlr-2009-3 
of networks and finally extending over different scales. Jauhiainen (2005) has similarly divided studies of urban space into four broad categories: space as materiality - space exists as a product of economic activity; space as distinctive character - space is seen as consisting of borders, the speciality of location is stressed; space as activity - the focus is given to socio-spatial relation in space; and space as contextuality - space exists only after it has been given a meaning through human consciousness as well as by the means of material resources. Now after very shortly having reviewed the concept of place in some of the researches and stressed upon the need for interdisciplinary research on place studies we continue with explaining how we approach to place.

When defining place, we use the definition that has been applied by several authors (Massey, 1994; Agnew, 1987; Martin, 2003). Place for us is socially constructed and operating, including interaction between people and groups, institutionalized land uses, political and economic decisions, and the language of representation. This definition already stresses that place should be looked at interdisciplinary, however, authors claim that there are some shortages in the current research. Firstly, the literature of place making mainly deals with wider scales and especially authors investigating global influences on places rarely engage with the topics of place meaning nor identity [see for example Massey (2003)]. Global processes are viewed only as having material influences on places and not having to do anything with ever changing place meanings.

Those authors who aim to study place meanings, however, are constrained with quite narrow scales ending usually with nation frames, although mainly the literature investigates personal place meanings and identities. When researching meanings in personal scale influences of global economy changes, national politics etc. are entirely left aside.

By this, authors would like to stress that physical changes in place and meanings are thoroughly related and influenced by various scales. Auburn and Barnes (2006) have suggested dividing the meaning-making process into four categories: personal, local, national and supranational. To clarify the following the article authors have used this categorization, although we suggest that these categories are more constructed than natural. All these different scales finally mix through individual consciousness. The meanings which a person attaches to places are similarly influenced by personal experiences and global politics. We give an example of how different dimensions are intermingled when constructing meanings. The meaning of McDonald's may be influenced by a person's eating habits, his participation in some organizations - for example animal protection unit, the state's policy towards globalization, the position it has in the city space etc.

Finally, the connection between the place meanings and identity also needs to be reviewed. Place identity, when using the simplest clarification, characterizes people as meaning characterizes places. People's identities are created through defining themselves in relation to places (Jorgensen and Stedman, 2001). As meaning-making, also this process takes place in a complex pattern of conscious and unconscious ideas, beliefs, preferences, memories, ideas, feelings, values, goals and behavioral tendencies and skills relevant to this environment (Vorkinn and Riese, 2001) As place meanings can exist in different levels so do identities. Paasi (2001) has differentiated identities in three levels - regional, collective and individual. Still authors suggest that there also exists supranational identity for people, only one example could be given by the means of states who identify themselves through belonging to the EU.

Next we will give an overview of place meanings and making in different scales. It must be stressed, however, that this article concentrates more on not criticizing various disciplines, but rather tries to put their ideas together by showing the wholeness of place.

\section{$2.1 \quad$ Supranational place making, place meanings}

Manzo (2003) brings an example of how ideologies are used in supranational place-making strategies. Different ideologies not only influence the concrete space by producing different kind of buildings and city patterns but their actual influence lies far deeper. Firstly, ideologies influence 
people's practices. For example, the economy of shortage during socialism made people hoard products (Kornai, 2000). With this practice various storages were needed to store the products, for example garages were used for this purpose during the Soviet time. Argenbright (1999) has given an example of how meaning making process in post-socialist city differs from those of capitalist cities since people less give meanings to public spaces that are still being connected with state power. Ideologies also influence economical and political circumstances and social relations of people (Scott, 1998). All this is represented through dissimilar place meanings.

Recently a lot of literature focuses on globalization and the global scale of places. Very many have claimed that due to globalization time is becoming more important than space (Jessop et al., 2008; Kirsch, 1995, etc.) and humanistic geographers have viewed the placelessness as emerging monolithic landscape that spreads over spaces (Relph, 1976). Terkenli (2001) has suggested that with a process of deworldment a new collective sense of place at the global level has emerged. However, Sheppard (2002) has debated this view and argues that place in globalizing context still matters a lot using the importance of territorial economies and governance structures on business decisions as an example. Globalization, according to him, may well have eliminated space but not place, which means that no longer locational advantage is important but instead place based characters, in determining the relative attractiveness of place for capital. He even goes as far as stating that actually global economy creates more inequalities and differences between places, by preferring some and neglecting other places. Also, Massey (1994) has brought out that globalization develops porosity of place - communication with other places, that is vital for the survival of regions and communities.

Globalization influences the meanings of states. For instance, the so-called Third World states have become the depository, container or low-cost production sites in Western paradigm, some places have acquired the meaning of demand nodes etc. Globalization changes the meanings of places on the individual level as well, for example, people's evaluation of global businesses depends on how they (state, region) see the globalization, whether as destructive force to regionality, or as force which gives prosperity to everyone etc.

One example of supranational place making is also the discourse of researchers and planners (Lefebvre called this conceived space). Probably the most obvious example is high-modernism and Le Corbusier's ideas about city planning which influenced the destiny of various cities. Not only did the discourse intend to change the physical form of cities but also the practices that were preformed by individuals by introducing zoning policies (Scott, 1998). Today those discourses continue to influence the meanings attached to places in various scales also through the regimes of so called ideal landscapes. Researchers are starting to more and more intervene in planning policies and there exist a wide literature on place making which is used by community making throughout the world (see for example http://www.pps.org/).

Places are also changed by various technologies (Sheppard, 2002). The introducing of Fordist production model transformed the world. Sheppard (2002) also when viewing different factors that city character is influenced by, brings out hard factors such as access to labor, raw materials and markets and soft factors, cultural and social capital. Molotch (2002) has lead attention to the transforming effect of migration. Migration takes place for various reasons being sometimes carried by previous meanings of cities/countries and reproducing/reinforcing these. He has shown how such reproduction of meanings takes place in U.S. cities.

Supranational place making also comprises the meanings that unite different groups based on age, gender, religion (Molotch et al., 2000). For example home has been throughout the history associated with women (Butler, 1990). These meanings can differ between various regions as well, catholic church has totally different meanings in Warsaw or in Israel but also in Northern Ireland and Republic of Ireland.

Finally, the contribution of Relph (1976) should also be reviewed as he has introduced the term mass-identity which according to him refers to the meanings created by opinion-makers

Living Reviews in Landscape Research

http://www. livingreviews.org/lrlr-2009-3 
and provided ready made through media. Mass identities are not only based on symbols and significances, but also on stereotypes. Alexander (2002) has discussed the meaning of holocaust and of the spaces connected to it in various memorials. He finds that historical event is used for far wider context and spaces created in honor to that usually denote not just to the destiny of one nation but more to the understandings of bad and good as also to universal suffering etc. Historical events can create various meanings to places.

\section{$2.2 \quad$ National place making}

Friedmann (2007) has very thoroughly discussed how place making appears in the level of state. State creates the images of places by constraining everyday life by deciding what activities are allowed at certain times of the day or night, who may or may not be seen on the street, what forms of public behavior are permitted and which are not, what kind of traffic may circulate, what sort of structures may be built and for what purposes. The influence of state is even wider and starts when raising children and introducing them to general norms, for example people do not throw rubbish out of the window because state has forbidden it. State is empowered to regulate everyday life in the public spaces of the city but, not only, the state also regulates our private life by punishing us for playing loud music at night etc. State's presence is at the same time visible and invisible through various institutions like the police, social workers, surveillance cameras, systems of licensing and permits, standards for constructions etc. (Friedmann, 2007).

Another example of the national scale of place making has already been discussed under the planning activities. Different plans create spaces endowed with meaning by stating what their purpose is and how they should be used. It also brings out the conflict between the state and the individual, although the state has somehow regulated the use of its spaces the actual activity of individuals does not always stay in these borders and places often have alternative uses. State planning policies can also act in more hidden ways. Davis (1990) gives examples of how the government in Los Angeles decided to exchange the seats in bus stops to ones impossible to sit on. This strategy actually was meant to eliminate homeless people from the city picture.

The state policy also influences national and other scales of place making. For instance if the state has been following neo-liberal policies the communities are been assumed to take care of the local facilities (Martin, 2003). This kind of policy also creates more segregation which influences the spatial character of the cities. As a result different districts obtain various meanings.

When talking about the national scale of place meanings, those describing various states, cannot be left aside. States fight in global means to attract investments and try to present their country in certain ways (Molotch et al., 2000). The production of meanings is also present in international policies where states try to identify themselves and create various beneficial images. An example can be given when viewing the national policy of Estonia. Estonia very strongly tries to identify itself through belonging to Europe or among Northern countries. This policy is the answer to the Soviet period and denotes to the try of cutting itself loose from Russia. The fact that about $30 \%$ of Estonia's population is still Russian-speaking is usually not presented. Sometimes such national identities are also created by narratives.

State also gives meanings to places when (re)naming them (Bird, 2002). For instance most of the post-Soviet countries have renamed their streets after independence (see, for instance Light, 2004; Czepczyñski, 2008). Naming of course is not only the means state uses to attach meanings. People and groups both actively use this method as well.

\section{$2.3 \quad$ Local place making}

We already previously discussed a bit over the changing role that locality has in place making. Various authors (Massey, 1994; Molotch et al., 2000, etc.) agree on the fact that locality still 
matters. Molotch et al. (2000) has reasoned that locality still matters since similar outside forces can have very different consequences depending on the local context. One difference lies on how various communities deal with comparable outside forces. Paasi (2001) notes that ideology, history and social transformation all come together in different ways in particular place. This all has lead to the conclusion that locality still matters.

Paasi (2001) has seen local identity as counterforce to globalization and has claimed that it refers to people's attempt to mark boundaries. Regional identity is created in distinctive manner, regions try to distinguish themselves by natural, cultural elements and inhabitants. In some way as Sheppard (2002) has noted, global economy is reinforcing distinction because it now more than ever values distinctive characters of place instead of position. These distinctions are also used in discourses of science, politics, cultural activism. However such narratives are not only used for economic etc. purposes but it also lets people create the sense of self by acknowledging who and what they are and sometimes adopting ready-made identities.

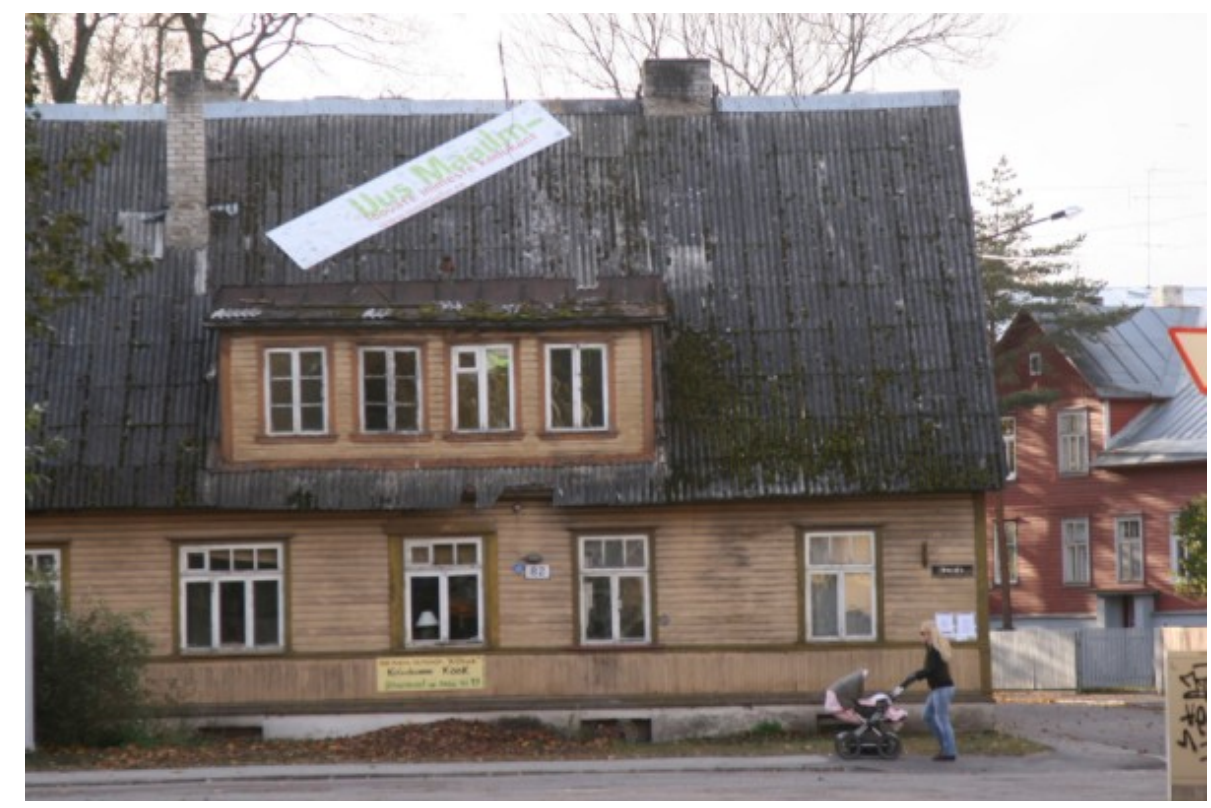

Figure 1: Creation of urban places in the Uus Maailm suburb of Tallinn. The slogan on the roof reads "Uus Maailm (New World) - homeplace of creative people". Photo Maarja Saar, Oct 22, 2008.

These ready-made identities are often created through historical association Leith (2006). Usually common history has not been directly experienced and is thus carried on by stories and creating narratives themselves (These narratives can also act in the state level). Narratives are reinforced through traditional activities. Devine-Wright and Lyons (1997) have claimed that the more actively an individual is involved in traditional activities the stronger is the bond between the individual and places. Another bounding character that influences people's identity is common culture. Culture involves common socialization process which takes place through sharing similar experiences, signs and symbols. The altering effect of culture has especially been researched by landscape anthropologists such as Low (1994); Hirsch and O'Hanlon (1995).

Community making has complicated the relationship with place meanings. On one hand those sharing similar experiences and having common purposes unite under citizen movements, on the other hand this activity transforms previous meanings. Neighborhood organizations use various narratives such as previously discussed historical and cultural but also physical natural and experimental. Martin (2003) has called such narratives place frames. Place frames are constantly

Living Reviews in Landscape Research

http://www. livingreviews.org/lrlr-2009-3 
in transition and are remade by creating common ground for collective action and shaping people's ideas about places. New meanings are being created by bringing out common experiences, interests and values. Often however what is more stressed upon are the characters that distinguish people from others. Davis (1990) has thoroughly discussed organizations that in their activity rely on common interests. He brings out the role of NIMBY (not in my backyard) attitude as one reason for activism. According to Martin (2003) place frames are what have the first effect when connecting people's personal meanings with broader scale.

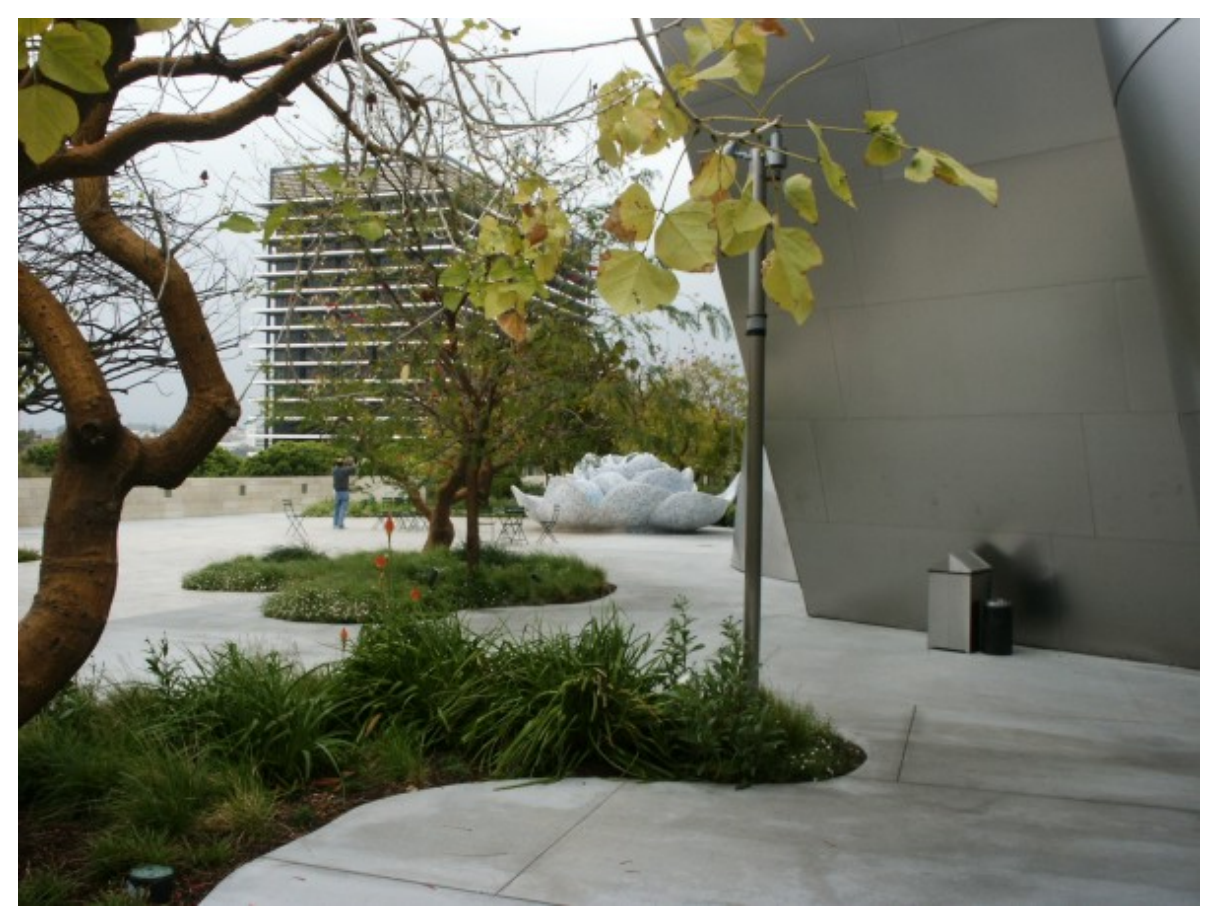

Figure 2: New urban nature in the center of Los Angeles. Disney Concert Hall. Photo Hannes Palang, Apr 3, 2004.

Paasi (2001) has further noted the related character of personal and collective meanings by stating that people today have more diversified regional backgrounds and the personal histories that process of regional identification is becoming mixed. People use their previous identities formed in different localities in order to attach meanings to new places.

\subsection{Individual place making}

A lot of attention has been given to the meanings people attach to places in individual level and how it contributes to their identity. One of the reasons, in fact, why people give meanings to places is the need to discover and evolve their identity. Through some place people can experience reflection, introspection, self-understanding etc. Individual's identity may form in contribution to many places and their meanings (Manzo, 2005).

Sometimes places act as important markers in people's lives. Places can acquire meaning through significant experiences (trauma, loss) and through the experiences of change and transition (moving). Places related to these experiences can become meaningful regardless of being negative or positive. (Manzo, 2005) People can however also consciously decide to give positive meanings to some places connected to change. Friedmann (2007) has given an example of how people when 
moving to new place try to establish relationship with places by for instance chatting with locals, learning street names etc. Sometimes meanings precede moving, people may decide to move to places that are more concurrent with their sense of self (Twigger-Ross and Uzzell, 1996). People choose living areas to express who they are so the relationship between meanings and change is two folded, change can lead to meaning making or positive meanings can lead to change.

Places can become meaningful to people because of the relations they have had with other people for instance people living there - friends, acquaintances, relatives (Gustafson, 2001). We have already previously discussed how the sense of community helps in place making. Relph (1976) has noted the importance that people bring to places by stating that in the absence of right people places are quickly drained of meaning. Relationships with other people are a part of collective self defining as also individual place making through special relationships with only one or few persons. The connection, however, is two folded - places can become meaningful through social relationships but special places help to create meaningful relationships as well.

Places have a great role in reminding us of our past. The connection to history that places form extends as already mentioned over all the categories of place making. On the individual level they act for us as connections with special times or occasions in our life (Shamsuddin and Ujang, 2008). A place can remind us of a certain occasion or can be like a path mark of the point we were back then. Places can also remind us of some particular periods in our life through nostalgia (Hay, 1998; Gustafson, 2001), usually childhood memories are an important example of how places became meaningful (Derr, 2002) This meaning can become especially strong when the places as they were are not there anymore or are rarely used by the person relating it immediately to the particular time (Smaldone et al., 2005). Places can also act contrary and reflect continuity in our lives (Smaldone et al., 2005). But in other circumstances places are valued for some decisions and changes that are connected to these and for interrupting continuity.

Places are also used for awaking certain feelings like comfort, security, belonging, being anchored, self-expression, and freedom to be oneself (Smaldone et al., 2005). All these meanings can sometimes also be seen as unifying certain groups, for instance, gays gathering to one district because it provides them with the feeling of safety. Feelings awaken by some place can play a role in forming and maintaining place connections and place-identity (Smaldone et al., 2005).

Some places may acquire meaning through certain activities (Tuan, 1977). Derr (2002) has given an example of how children make places meaningful by climbing trees, paying games, making forts etc. For grownups similar activities exist which are sometimes part of their everyday routines like visiting a cafe.

Living Reviews in Landscape Research

http://www. livingreviews.org/lrlr-2009-3 


\section{$3 \quad$ Unifying the dimension}

As we have already previously suggested, the categories that are being used here to distinguish between different scales where place meanings are created, must not be taken strictly. Firstly, there exists an array of place meanings that cannot be united under one dimension. An example can be given by pointing to meanings that are attached to places because of their physical attributes (Yuen, 2005). Such meanings can well extend over cultures, for instance, in the Western world skyscrapers usually symbolize power. However these meanings can well be very personal and depend more on person's inner self. For example there has been a lot of discussion over the preferred landscapes (Tveit et al., 2006; Yang and Kaplan, 1990; Palmer, 1997) and it has been suggested by various authors that the evaluation of landscape is very personal process (Abu-Ghazzeh, 2000; Vorkinn and Riese, 2001). Another example of how meanings extend over the categories is the places that obtain meaning through events. These events may be of global scale (9/11), festivals etc. or be connected with individual or family occasions (celebrating some festivities) (Tuan, 1977). Finally also the question of ownership extends over various categories. Place meanings are influenced by ownership relations. The ownership here can reflect the state's ownership of city space where they decide who and when can move (Cresswell, 1996) or also the individual ownership which connects people with places and creates a sense of proud (Hernández et al., 2007).

The second reason why we need not separate these different categories is the fact that they are all interlaced. It should be noted that the factors that influence place meanings are different from those dimensions that place meanings can be divided to. Here we have discussed both factors. People, when asked, often miss the effect that wider context like politics and economics, has to their identity. For instance the research of Gustafson (2001) demonstrates that when interviewing people his results show only a few meanings that are shaped by wider forces. This indicates that these effects should be noted by researchers themselves and added to analysis.

How are place meanings and created identity related to place attachment? Leith (2006) has concluded that the most important contributors towards place attachment are functional, emotional and social meanings. So what is the difference between place identity and attachment? The basic difference is the fact that the latter is used in a positive context (Altman and Low, 1992). Although various authors (Shamai, 1991; Leith, 2006) have suggested that place attachment is created by positive meanings only we still claim that this is misleading. Negative meanings can well influence place attachment by creating contrasts. Some places can gain positive value through comparison.

There is a lot of literature on how physical characteristics of neighborhood are connected with sense of community and thus also to place attachment. For instance Mannarini et al. (2006) and Kelly and Hosking (2008) both have argued that people's perceptions of their socio-physical environment strongly influence people's sense of community and thus their place attachment. This argument is debated by Brain (2005) who uses ghettos as an example to prove that socio-physical appearance may not be that important at all since residents of ghettos usually share a great sense of belonging. Tuan (1977) has also stressed on the subjective character of the perception of sociophysical environment. He gives an example of how one can have very emotional and personal relationship with his hometown although this can totally lack in architectural distinction and historical glamor. We also claim that place attachment must not be connected with quantitatively measurable characteristics. When understanding place attachment, the key is to analyze place meanings.

Another shortcoming that is currently noticeable in attachment studies is the fact that most of the literature in place attachment studies concentrates on individual attachment (Manzo and Perkins, 2006). What is quite missing is the discussion of how place attachment is related to larger socio-political context. Various authors (Dixon and Durrheim, 2000; Devine-Wright and Lyons, 1997) argue that writings about identity and attachment need to be viewed in the context of wider social, historical and political milieu. This very clearly points out the need to acknowledge that 
the process of attaching to place extends towards all the categories of place meaning. For instance Altman and Low (1992) have described six different processes that can symbolically link people and a place: genealogical linkage through history or family lineage; linkage through loss or destruction of land or community; economic linkage through ownership, inheritance or politics; cosmological linkage through spiritual relationships; linkage through religious or secular pilgrimages; narrative linkage through story-telling and naming the places. As can be seen, most of these factors mentioned here actually comprise wider scales than only individual place making and are common practices within the group of people.

The previous discussion clearly shows us why it is important to include various scales of place meanings into place attachment studies. Firstly, the process of attaching to places extends over various scales and cannot be understood as a very personal matter only. Secondly, places meanings are important part in attaching to place and place attachment can be better grasped when studying meanings than when researching quantitative factors. However it should be noted that there also exist conflicting views about the importance of place meanings in creating place attachment. Hernández et al. (2007) for instance, have suggested that place attachment must not always be connected with identity and meanings, referring to the situation when someone likes to live in a place and wants to remain there but does not feel that this place is a part of their identity. This case however has been named place dependence rather than attachment. Place dependence is used to refer to a situation when two places are compared with utilitarian perspectives in mind and having little emotional involvement (Smaldone et al., 2005). 


\section{Place attachment and exclusion}

When discussing place attachment and meanings also the possible negative side of place identity and attachment should be reviewed. Manzo (2003) has referred that emotional connections to places can be shaped by negative experiences of omission as well. The politics of belonging involves also decision about who belongs to the place and who does not Malone (1999). Manzo (2003) points out that some people's sense of rootedness and belonging is obtained by excluding others.

This kind of exclusion can exist over various levels. Paasi (2001); Fried (2000) and DevineWright and Lyons (1997) have given examples of exclusion in wider scale. They all have claimed that belief in deep, fixed link between a specific group and territory may lead to process of social exclusion and othering. Fried (2000) has stated that the extreme commitment to culturally-identified territories can lead to the efforts to obtain hegemonic control. Paasi (2001) discusses the problem of migration politics and refugee problem in the light of place identity. Fried (2000) notes that place attachment in its extreme cases can entail territorial competition, warfare, tribal conflict, mass murder and even genocide. According to Manzo (2003) those conflicts partly rely on the question whose memories and history is preserved in places and why. This especially comes into question if some territories, memorial landscapes or communal places are shared by various groups (Entrikin, 2002) and each of the groups associates with these places different values and feelings (Devine-Wright and Lyons, 1997).

Malone (1999) has discussed in more detail the exclusion of people from places during everyday politics. According to her, people can be excluded from public spaces in two ways: either through the exclusionary practices of outside agents or by self-policing. One example of how outside agents perform their elimination policies is given by Cresswell (1996) who describes how the government of New York City has decided to remove homeless from public places like the Grand Central Station. Also, various neighborhood organizations obtain their identity by defining what they are not and by drawing upon class, ethnicity, gender, race, sexuality etc. Davis (1990) has given an example of how neighborhood activism can act as exclusionary policy by drawing attention to the conflict between rich house owners and immigrants in Los Angeles. The general understanding of house owners can be given with the lines of one Diamond Bar council candidate: "I do not want to see graffiti, gangs and prostitution - I want safety". Rich house owners had already decided that multistory housing with poorer residents brings more criminality to their living area and they used neighborhood policies by excluding those poorer inhabitants. Manzo (2003) notes that there are strict regulations on the usage of space and those who overstep the boundaries imposed upon them by society usually suffer consequences through harassment and violence.

Entrikin (2002) has discussed various strategies of dealing with "the bad side" of place attachment. The key, according to him, lies in respecting and recognizing the particularistic group cultural identities of citizens. Competition among different ethnic groups for socio-spatial expression greatly lessens as each group role and inheritance is acknowledged (Manzo and Perkins, 2006). All the members of community must be given a chance for active and full participation in place making policy. In multicultural society public debate and deliberation and rules that allow cultures to sustain themselves should be followed. 


\section{$5 \quad$ Place-making and change}

Communities change values and aspirations, individuals change - so the sense of the place also changes (sense of place here is defined as comprising both place attachment and meanings) (Jivén and Larkham, 2003). On the one hand, people inflict landscape changes, on the other hand, when space changes then also lifestyle, culture and attitude transform (Antrop, 2003). Changing places can cause the change of people's values but people's values can change landscape changes.

Jivén and Larkham (2003) have criticized planners for not taking into account the changing values. Historic preservation policies are not aimed at telling dynamic stories in which urban life is constructing itself, but instead are aimed at establishing a static past when things were nicer. They state that the sense of place cannot be created by professional intervention although conditions under which place making is taking place can be promoted. So place making process is mainly done by people and with changing people we have also ever changing practices. Relationships to the outside world are reflections of our inside world so that as a person grows and collects experiences, the external world is enriched by the inner potential of the individual (Manzo, 2003). The relationships with places reflect the ongoing process of people making their own identity. For example some adults reproduce special places of childhood in their current residence, while others replay unresolved childhood conflicts (Manzo, 2003).

Place meanings for people can also change through experiences of tragedy or loss (Manzo, 2003). One of the examples is the transformation of place identity when loosing a friend whom the place was connected to. This place does not seem so positive to us anymore.

Friedmann (2007) explains changing of place identities as a result of population movement, aging, new construction, demolitions, floods, warfare, new technologies and customs etc. But changing place meaning can be a conscious process as well. Gustafson (2001) has given an example of how people try to connect themselves with place by forging social relations, acquiring knowledge or by physically reshaping the place.

One widely argued topic is how globalization affects place making and locality. It is believed that globalization creates deterritorialized cultures and places change through migration, economic change. Still, McKay and Brady (2005) argue that places have always joined together to make regions; and porosity of borders has always been essential to place-making. Their conclusion is that the nature of place might be changing with global movements of people and information, but not the place itself. Friedmann (2007, p 277) has written with reference to Clifford Geertz: "'no one lives in the world in general' but in localities where human ties and familiar landscapes give rise to sentiments of place".

Yet, it is still correct that the meanings of places become less stable as more and more personal experiences and social relations are removed from the local context (Cook et al., 2007). So people nowadays need more time to establish the sense of place and attach to localities. Bonding to a place for a lifetime now involves spending many decades together, modern people are instead finding suitable places for different stages of life (Hay, 1998).

Sometimes people do not cope with changing environment, practices - their sense of place gets lost (Cook et al., 2007). This has been detected in rural areas, where places are disappearing and new ones have not yet been created (Friedmann, 2007). This loss happens partly because of people's need for continuity. Gustafson (2001) has emphasized the sense of continuity of the self in creating place attachment.

Living Reviews in Landscape Research

http://www. livingreviews.org/lrlr-2009-3 


\section{Conclusion}

We have aimed to give an overview why place and place meanings should be researched interdisciplinary. We attempted to bind together place making and place attachment studies and show their very interlacing manner. Various dimensions of place meanings, as the main key to simplify understanding, were introduced. We divided place meanings into four interlacing categories - supranational, national, local and individual. We gave some examples of each category but our list of how meanings are influenced is by no means final. Rather, these categories were used to show how meaning construction actually spreads over the differing dimensions and extends over the individual and collective scale where it is often analyzed. There still exists the need for interdisciplinary research methods as our analysis denotes that individual interviews do not reflect wider identities. We suggest that the phenomenological and the structural approach should learn from each other.

We also suggest that attachment studies should involve place meanings into their research as they are strongly related. Place attachment cannot be studied only on the basis of, for instance, physical attributes of the area or people's perceptions. On the other hand, attachment also influences meanings given to places, so both environmental psychologists and humanistic geographers have a lot to learn from each other.

We also find that policy researchers should deal more with places and conflicting meanings. As indicated in Section 4, 'Place attachment and exclusion', often meanings that are attached to places by different groups can be a root to a community conflict. The importance of places in policy should be more noted. Also historical researchers are starting to deal more with places which are very important for understanding the various dimensions of places as places often carry historical significances with them.

Finally, we find studying place meanings highly beneficial for understanding the ongoing changes in our environment. Place meanings should be definitely involved in conservation strategies. Place meanings also act as a beneficial manipulation strategy. 


\section{Acknowledgements}

This research was supported by the European Union through the European Regional Development Fund, the Estonian Science Foundation grant No. 6986 "Place making in urban landscapes", Estonian Ministry of Education target-financed project SF0130033s07 and by the European Union through the European Regional Development Fund (CECT). 


\section{References}

Abu-Ghazzeh, T.M. (2000), "Environmental Messages in Multiple-family Housing: territory and personalization", Landscape Research, 25(1): 97-115, doi:10.1080/014263900113190. (Cited on page 13.)

Agnew, J.A. (1987), Place and politics: The Geographical Mediation of State and Society, Boston (Allen \& Unwin). (Cited on page 7.)

Alexander, J.C. (2002), "On the Social Construction of Moral Universals: The 'Holocaust' from War Crime to Trauma Drama", European Journal of Social Theory, 5(1): 5-85, doi: 10.1177/1368431002005001001. (Cited on page 9.)

Altman, I., Low, S.M. (Eds.) (1992), Place Attachment, vol. 12 of Human behavior and environments, New York (Plenum Press). (Cited on pages 13 and 14.)

Alumäe, H., Printsmann, A., Palang, H. (2003), "Cultural and Historical Values in Landscape Planning: Locals' Perception", in Landscape Interfaces: Cultural Heritage in Changing Landscapes, (Eds.) Palang, H., Fry, G., pp. 125-146, Dordrecht (Kluwer). (Cited on page 5.)

Antrop, M. (2003), "Continuity and change in landscapes", in Multifunctional landscapes, vol 3: Continuity and Change, (Eds.) Mander, Ü., Antrop, M., Multifunctional landscapes, held in Roskilde, Denmark in 2000, vol. 16 of Advances in Ecological Sciences, pp. 199-215, Southampton (Wessex Institute of Techonolgy Press). (Cited on page 16.)

Argenbright, R. (1999), "Remaking Moscow: New Places, New Selves", Geographical Review, 89 (1): 1-22. (Cited on page 8.)

Auburn, T., Barnes, R. (2006), "Producing place: A neo-Schutzian perspective on the "psychology of place"", Geographical Review, 26(1): 38-50, doi:10.1016/j.jenvp.2006.03.002. (Cited on page 7.)

Bird, S.E. (2002), "It Makes Sense to Us: Cultural Identity in Local Legends of Place", Journal of Contemporary Ethnography, 31(5): 519-547, doi:10.1177/089124102236541. (Cited on page 9.)

Brain, D. (2005), "From Good Neighborhoods to Sustainable Cities: Social Science and the Social Agenda of the New Urbanism", International Regional Science Review, 28(2): 217-238, doi: 10.1177/0160017605275161. (Cited on page 13.)

Butler, J. (1990), Gender Trouble, Thinking Gender, New York (Routledge). (Cited on page 8.)

Cook, C.C., Martin, P., Yearns, M., Damhorst, M.L. (2007), “Attachment to 'Place' and Coping with Losses in Changed Communities: A Paradox for Aging Adults", Family and Consumer Sciences Research Journal, 35(3): 201-214, doi:10.1177/1077727X06296794. (Cited on pages 5 and 16.)

Cosgrove, D.E. (1998), Social Formation and Symbolic Landscape, Madison (University of Wisconsin Press). Google Books. (Cited on page 5.)

Cresswell, T. (1996), In Place/Out of Place: Geography, Ideology and Transgression, Minneapolis (University of Minnesota Press). (Cited on pages 5, 13, and 15.)

Cresswell, T. (2003), "Landscape and the Obliteration of Practice", in Handbook of Cultural Geography, (Eds.) Anderson, K., Domosh, M., Pile, S., Thrift, N., pp. 269-281, London (Sage). (Cited on page 5.) 
Czepczyñski, M. (2008), Cultural Landscapes of Post-Socialist Cities. Representation of Powers and Needs, Aldershot (Ashgate). (Cited on page 9.)

Daniel, T., Vining, J. (1983), "Methodological issues in the assessment of landscape quality", in Behavior and the Natural Environment, (Eds.) Altman, I., Wohlwill, J.F., vol. 6 of Human behavior and environment, pp. 39-83, New York (Plenum Press). (Cited on page 5.)

Davis, M. (1990), City of Quartz: Excavating the Future in Los Angeles, New York (Vintage Books). (Cited on pages 9, 11, and 15.)

Derr, V. (2002), "Children's Sense of Place in Northern New Mexico", Journal of Environmental Psychology, 22(1-2): 125-137, doi:10.1006/jevp.2002.0252. (Cited on pages 5 and 12.)

Devine-Wright, P., Lyons, E. (1997), "Remembering Pasts and Representing Places: The Construction of National Identities in Ireland", Journal of Environmental Psychology, 17(1): 33-45, doi:10.1006/jevp.1996.0037. (Cited on pages 10, 13, and 15.)

Dixon, J., Durrheim, K. (2000), "Displacing place-identity: A discursive approach to locating self and other", British Journal of Social Psychology, 39(1): 27-44. (Cited on page 13.)

Entrikin, J.N. (1991), The Betweenness of Place: Towards a Geography of Modernity, Baltimore (Johns Hopkins University Press). (Cited on pages 5 and 6.)

Entrikin, J.N. (2002), "Democratic place-making and multiculturalism", Geografiska Annaler: Series B, Human Geography, 84(1): 19-25, doi:10.1111/j.0435-3684.2002.00110.x. (Cited on page 15.)

Fried, M. (2000), "Continuities and Discontinuities of Place", Journal of Environmental Psychology, 20(3): 193-205, doi:10.1006/jevp.1999.0154. (Cited on pages 5 and 15.)

Friedmann, J. (2007), "Reflections on Place and Place-making in the Cities of China", International Journal of Urban and Regional Research, 31(2): 257-279, doi:10.1111/j.1468-2427.2007.00726.x. (Cited on pages 9, 11, and 16.)

Ghose, R., Elwood, S. (2003), "Public Participation GIS and Local Political Context: Propositions and Research Directions", URISA Journal, 15(APA2): 17-24. URL (cited on 07 July 2009): http://www.urisa.org/node/807. Proceedings of the Workshop on Access to Geographic Information and Participatory Approaches in Using Geographic Information, held in Spoleto, Italy, 5-9 December 2001. (Cited on page 5.)

Gobster, P.H., Nassauer, J.I., Daniel, T.C., Fry, G. (2007), "The shared landscape: what does aesthetics have to do with ecology", Landscape Ecology, 22(7): 959-972, doi:10.1007/s10980007-9110-x. (Cited on page 5.)

Gustafson, P. (2001), "Meanings of Place: Everyday Experience and Theoretical Conceptualizations", Journal of Environmental Psychology, 21(1): 5-16, doi:10.1006/jevp.2000.0185. (Cited on pages 12,13 , and 16.)

Hay, R. (1998), "Sense of Place in Developmental Context", Journal of Environmental Psychology, 18(1): 5-29, doi:10.1006/jevp.1997.0060. (Cited on pages 12 and 16.)

Healey, P. (1996), "The communicative turn in planning theory and its implications for spatial strategy formations", Environment and Planning B: Planning and Design, 23(2): 217-234, doi: 10.1068/b230217. (Cited on page 5.)

Living Reviews in Landscape Research

http://www. livingreviews.org/lrlr-2009-3 
Healey, P. (1998), "Building institutional capacity through collaborative approaches to urban planning", Environment and Planning A, 30(9): 1531-1546, doi:10.1068/a301531. (Cited on page 5.)

Hernández, B., Hidalgo, M.C., Salazar-Laplace, M.E., Hess, S. (2007), "Place Attachment and Place Identity in Natives and Non-natives", Journal of Environmental Psychology, 27(4): 310319, doi:10.1016/j.jenvp.2007.06.003. (Cited on pages 13 and 14.)

Hirsch, E., O'Hanlon, M. (Eds.) (1995), The Anthropology of Landscape: Perspectives on Place and Space, Oxford (Clarendon Press). (Cited on page 10.)

Hubbard, P., Kitchin, R., Valentine, G. (Eds.) (2004), Key Thinkers on Space and Place, London; Thousand Oaks, CA (SAGE Publications). (Cited on page 6.)

Jauhiainen, J.S. (2005), Linnageograafia. Linnad ja linnauurimus modernismist postmodernismini, Tallinn (Eesti Kunstiakadeemia). (Cited on page 7.)

Jessop, B., Brenner, N., Jones, M. (2008), "Theorizing sociospatial relations", Environment and Planning D: Society and Space, 26(3): 389-401, doi:10.1068/d9107. (Cited on pages 6 and 8. )

Jivén, G., Larkham, P.J. (2003), "Sense of Place, Authenticity and Character: A Commentary", Journal of Urban Design, 8(1): 67-81, doi:10.1080/1357480032000064773. (Cited on page 16.)

Jones, M. (2003), "The Concept of Cultural Landscape: Discourse and Narratives", in Landscape Interfaces: Cultural Heritage in Changing Landscapes, (Eds.) Palang, H., Fry, G., pp. 21-52, Dordrecht (Kluwer). (Cited on page 5.)

Jorgensen, B.S., Stedman, R.C. (2001), "Sense of Place as an Attitude: Lakeshore Owners Attitudes Toward Their Properties", Journal of Environmental Psychology, 21(3): 233-248, doi: 10.1006/jevp.2001.0226. (Cited on page 7.)

Kaur, E., Palang, H., Sooväli, H. (2004), "Landscapes in Change - Opposing Attitudes in Saaremaa, Estonia", Landscape and Urban Planning, 67(1-4): 109-120, doi:10.1016/S01692046(03)00032-X. (Cited on page 5.)

Kelly, G., Hosking, K. (2008), "Nonpermanent Residents, Place Attachment, and 'Sea Change' Communities", Environment and Behavior, 40(4): 575-594, doi:10.1177/0013916507302246. (Cited on page 13.)

Kirsch, S. (1995), "The incredible shrinking world? Technology and the production of space", Environment and Planning D: Society and Space, 13(5): 529-555, doi:10.1068/d130529. (Cited on page 8.)

Kornai, J. (2000), "What the Change of System from Socialism to Capitalism Does and Does Not Mean", Journal of Economic Perspectives, 14(1): 27-42. (Cited on page 8.)

Lefebvre, H. (1991), The Production of Space, Oxford; Cambridge, MA (Blackwell). Google Books. (Cited on page 6.)

Leith, K.H. (2006), "'Home is where the heart is...or is it?': A phenomenological exploration of the meaning of home for older women in congregate housing", Journal of Aging Studies, 20(4): 317-333, doi:10.1016/j.jaging.2005.12.002. (Cited on pages 10 and 13.)

Lewis, P. (1979), "Defining a sense of place", in Sense of place: Mississippi, (Eds.) Prenshaw, P.W., McKee, J.O., Papers presented at a symposium held at the University of Southern Mississippi, Hattiesburg on October 5-6, 1978, pp. 28-30, Jackson, USA (University Press of Mississippi). (Cited on page 5.) 
Light, D. (2004), "Street names in Bucharest, 1990-1997: exploring the modern historical geographies of post-socialist change", Journal of Historical Geography, 30(1): 154-172, doi: 10.1016/S0305-7488(02)00102-0. (Cited on page 9.)

Low, S. (1994), "Place Attachment in Cultural Anthropology", National Geographical Journal of India, 40(1-4): 47-61. Special Issue on 'The Spirit and Power of Place'. (Cited on page 10.)

Luz, F. (2000), "Participatory Landscape Ecology - A Basis for Acceptance and Implementation", Landscape and Urban Planning, 50(1-3): 157-166, doi:10.1016/S0169-2046(00)00087-6. (Cited on page 5.)

Malone, K. (1999), "Growing Up in Cities as a model of participatory planning and 'place-making' with young people", Youth Studies Australia, 18(2): 17-23. (Cited on page 15.)

Mannarini, T., Tartaglia, S., Fedi, A., Greganti, K. (2006), "Image of neighborhood, selfimage and sense of community", Journal of Environmental Psychology, 26(3): 202-214, doi: 10.1016/j.jenvp.2006.07.008. (Cited on page 13.)

Manzo, L.C. (2003), "Beyond house and haven: toward a revisioning of emotional relationships with places", Journal of Environmental Psychology, 23(1): 47-61, doi:10.1016/S0272-4944(02)000749. (Cited on pages 5, 7, 15, and 16.)

Manzo, L.C. (2005), "For better or worse: exploring multiple dimensions of place meaning", Journal of Environmental Psychology, 25(1): 67-86, doi:10.1016/j.jenvp.2005.01.002. (Cited on page 11.)

Manzo, L.C., Perkins, D.D. (2006), "Finding Common Ground: The Importance of Place Attachment to Community Participation and Planning", Journal of Planning Literature, 20(4): 335-350, doi:10.1177/0885412205286160. (Cited on pages 5, 13, and 15.)

Martin, D.G. (2003), “'Place-Framing' as Place-Making: Constituting a Neighborhood for Organizing and Activism", Annals of the Association of American Geographers, 93(3): 730-750, doi:10.1111/1467-8306.9303011. (Cited on pages 7, 9, 10, and 11.)

Massey, D. (1994), Space, place and gender, Cambridge, UK (Polity Press). (Cited on pages 7, 8, and 9.)

Massey, D. (2003), "Negotiating Nonhuman/Human Place", Antipode, 37(2): 353-357, doi: 10.1111/j.0066-4812.2005.00497.x. (Cited on page 7.)

McKay, D., Brady, C. (2005), "Practices of place-making: Globalisation and locality in the Philippines", Asia Pacific Viewpoint, 46(2): 89-103, doi:10.1111/j.1467-8373.2005.00268.x. (Cited on page 16.)

Merrifield, A. (1993), "Place and space: a Lefebvrian reconciliation", Transactions of the Institute of British Geographers, 18(4): 516-531. (Cited on page 6.)

Molotch, H. (2002), "Place in product", International Journal of Urban and Regional Research, 26(4): 665-688, doi:10.1111/1468-2427.00410. (Cited on page 8.)

Molotch, H., Freudenburg, W., Paulsen, K.E. (2000), "History Repeats Itself, But How? City Character, Urban Tradition, and the Accomplishment of Place", American Sociological Review, 65(6): 791-823. (Cited on pages 8, 9, and 10.)

Nassauer, J.I., Opdam, P. (2008), "Design in science: extending the landscape ecology paradigm", Landscape Ecology, 23(6): 633-644, doi:10.1007/s10980-008-9226-7. (Cited on page 5.)

Living Reviews in Landscape Research

http://www . livingreviews . org//rlr-2009-3 
Olwig, K.R. (2002), Landscape, Nature and the Body Politic: From Britain's renaissance to America's new world, Madison (University of Wisconsin Press). Google Books. (Cited on page 5.)

Olwig, K.R. (2008), "Has 'geography' always been modern?: choros, (non)representation, performance, and the landscape", Environment and Planning A, 40(8): 1843-1861, doi: 10.1068/a40240. (Cited on page 5.)

Paasi, A. (2001), "Bounded spaces in the mobile world: Deconstructing 'regional identity" , Tijdschrift voor economische en sociale geografie, 93(2): 137-148, doi:10.1111/1467-9663.00190. (Cited on pages $7,10,11$, and 15.)

Palmer, J.F. (1997), "Stability of landscape perceptions in the face of landscape change", Landscape and Urban Planning, 37(1-2): 109-113, doi:10.1016/S0169-2046(96)00375-1. (Cited on page 13.)

Potschin, M.B., Haines-Young, R.H. (2006), "Editorial: Landscapes and sustainability", Landscape and Urban Planning, 75(3-4): 155-161, doi:10.1016/j.landurbplan.2005.03.006. (Cited on page 5.)

Relph, E. (1976), Place and placelessness, London (Pion). (Cited on pages 8 and 12.)

Scott, J.C. (1998), Seeing Like a State: How Certain Schemes to Improve the Human Condition Have Failed, New Haven (Yale University Press). (Cited on page 8.)

Selman, P.H. (2006), Planning at the Landscape Scale, London; New York (Routledge). Google Books. (Cited on page 5.)

Setten, G. (2004), "Naming and Claiming Discourse", in European Rural Landscapes: Persistence and Change in a Globalising Environment,, (Eds.) Palang, H., Sooväli, H., Antrop, M., Setten, G., pp. 67-82, Dordrecht (Kluwer). (Cited on page 5.)

Shamai, S. (1991), "Sense of place: an empirical measurement", Geoforum, 22(3): 347-358, doi: 10.1016/0016-7185(91)90017-K. (Cited on page 13.)

Shamsuddin, S., Ujang, N. (2008), "Making places: The role of attachment in creating the sense of place for traditional streets in Malaysia", Habitat International, 32(3): 399-409, doi: 10.1016/j.habitatint.2008.01.004. (Cited on page 12.)

Sheppard, E. (2002), "The Spaces and Times of Globalization: Place, Scale, Networks, and Positionality", Economic Geography, 78: 307-330, doi:10.1111/j.1944-8287.2002.tb00189.x. (Cited on pages 8 and 10.)

Smaldone, D., Harris, C., Sanyal, N. (2005), "An exploration of place as a process: The case of Jackson Hole, WY", Journal of Environmental Psychology, 25(4): 397-414, doi: 10.1016/j.jenvp.2005.12.003. (Cited on pages 12 and 14.)

Soini, K. (2001), "Exploring Human Dimensions of Multifunctional Landscapes through Mapping and Map-making", Landscape and Urban Planning, 57(3-4): 225-239, doi:10.1016/S01692046(01)00206-7. (Cited on page 5.)

Soja, E.W. (1996), Thirdspace: Journeys to Los Angeles and Other Real-and-imagined Places, Malden, MA (Blackwell). (Cited on page 6.)

Spirn, A.W. (1998), The Language of Landscape, New Haven; London (Yale University Press). (Cited on page 5.) 
Terkenli, T.S. (2001), "Towards a theory of the landscape: The Aegean landscape as cultural image", Landscape and Urban Planning, 57(3-4): 197-208, doi:10.1016/S0169-2046(01)00204-3. (Cited on page 8.)

Thrift, N. (2000), "Performing Cultures in the New Economy", Annals of the Association of American Geographers, 90(4): 674-692, doi:10.1111/0004-5608.00217. (Cited on page 6.)

Tuan, Y.-F. (1977), Space and Place: The Perspective of Experience, Minneapolis (University of Minnesota Press). (Cited on pages 12 and 13.)

Tveit, M., Ode, Å., Fry, G. (2006), "Key Concepts in a Framework for Analysing Visual Landscape Character", Landscape Research, 31(3): 229-255, doi:10.1080/01426390600783269. (Cited on page 13.)

Twigger-Ross, C.L., Uzzell, D.L. (1996), "Place and Identity Processes", Journal of Environmental Psychology, 16(3): 205-220, doi:10.1006/jevp.1996.0017. (Cited on page 12.)

Vorkinn, M., Riese, H. (2001), "Environmental Concern in a Local Context: The Significance of Place Attachment", Environment and Behavior, 33(2): 249-263, doi: 10.1177/00139160121972972. (Cited on pages 5, 7, and 13.)

Yang, B., Kaplan, R. (1990), "The Perception of Landscape Style: a Cross-cultural Comparison", Landscape and Urban Planning, 19(3): 251-262, doi:10.1016/0169-2046(90)90024-V. (Cited on page 13.)

Yuen, B. (2005), "Searching for place identity in Singapore", Habitat International, 29(2): 197-214, doi:10.1016/j.habitatint.2003.07.002. (Cited on pages 5 and 13.) 